\title{
The influenza challenge
}

\author{
Tim Nguyen, Sylvie Briand ${ }^{*}$ \\ From $16^{\text {th }}$ International Symposium on HIV and Emerging Infectious Diseases \\ Marseille, France. 24-26 March 2010
}

The presentation aims at introducing the various challenges faced at global level during the first pandemic of the 21st century.

On 25 April 2009, Mexico, under the International Health Regulations (2005) (IHR (2005)), notified the World Health Organization (WHO) about an outbreak of influenza-like illness. The responsible virus was identified a few days later by a WHO Collaborating Centre for Reference and Research on Influenza and a reference laboratory in Canada. This was the first reported event related to Influenza A (H1N1). In less than nine weeks, the pandemic virus spread in the six WHO regions. On 11 June 2009, WHO announced a pandemic phase 6.

Because of the threat posed by the re emergence of $\mathrm{A}(\mathrm{H} 5 \mathrm{~N} 1)$ virus in 2003 in Asia, most of the influenza experts and modellers were predicting that the next pandemic would start in Asia with similar characteristic as the H5N1 disease currently observed with a high case fatality ratio. One of the lessons learned is that predictions are very difficult when related to influenza viruses due their unpredictable evolution and the complexity of factors leading to pandemic.

The pandemic (H1N1) 09 is challenging in many aspects: firstly, the uncertainty about the evolution of the virus makes mid term preparedness and planning difficult.

Secondly, the weakness of some surveillance system does not allow an easy monitoring of the disease and its spread. The oseltamivir resistance monitoring has also been difficult in some parts of the world.

Thirdly, the modern communications means enable rumours to spread faster than ever. Public health authorities have to include risk communication in their strategy to respond to the outbreak.

The nature of this pandemic with moderate severity and very rapid spread imposed to revise national pandemic preparedness plans during the course of the

\footnotetext{
Global Influenza Programme, World Health Organization, Geneva,
} Switzerland event. The public and the media often misunderstood the rational for the modification.

The international community has responded quite well to the pandemic threat. In particular, countries have been especially collaborative regarding the exchange of information and the global access to supplies such as vaccine and antiviral drugs.

Published: 11 May 2010

doi:10.1186/1742-4690-7-S1-13

Cite this article as: Nguyen and Briand: The influenza challenge.

Retrovirology 2010 7(Suppl 1):13.

\author{
Submit your next manuscript to BioMed Central \\ and take full advantage of: \\ - Convenient online submission \\ - Thorough peer review \\ - No space constraints or color figure charges \\ - Immediate publication on acceptance \\ - Inclusion in PubMed, CAS, Scopus and Google Scholar \\ - Research which is freely available for redistribution \\ Submit your manuscript at \\ www.biomedcentral.com/submit
}

